\title{
Vegetative growth of grasslands based on hyper-temporal NDVI data from the Modis sensor
}

\author{
Marcos Cicarini Hott( ${ }^{(1)}$, Luis Marcelo Tavares de Carvalho(2), Mauro Antonio Homem Antunes ${ }^{(3)}$, \\ Polyanne Aguiar dos Santos ${ }^{(2)}$, Tássia Borges Arantes ${ }^{(2)}$, João Cesar de Resende ${ }^{(1)}$ \\ and Wadson Sebastião Duarte da Rocha ${ }^{(1)}$
}

\begin{abstract}
(1)Embrapa Gado de Leite, Rua Eugênio do Nascimento, no 610, Dom Bosco, CEP 36083-330 Juiz de Fora, MG, Brazil. E-mail: marcos.hott@embrapa.br, joaocesar.resende@embrapa.br, wadson.rocha@embrapa.br (2)Universidade Federal de Lavras, Campus Universitário, Caixa Postal 3037, CEP 37200-000 Lavras, MG, Brazil. E-mail: passarinho@dcf.ufla.br, polyanneaguiar@gmail.com, tassiabarantes@gmail.com ${ }^{(3)}$ Universidade Federal Rural do Rio de Janeiro, BR 465, Km 7, CEP 23890-000 Seropédica, RJ, Brazil. E-mail: homemantunes@gmail.com
\end{abstract}

Abstract - The objective of this work was to analyze the development of grasslands in Zona da Mata, in the state of Minas Gerais, Brazil, between 2000 and 2013, using a parameter based on the growth index of the normalized difference vegetation index (NDVI) from the moderate resolution imaging spectroradiometer (Modis) data series. Based on temporal NDVI profiles, which were used as indicators of edaphoclimatic conditions, the growth index (GI) was estimated for 16-day periods throughout the spring season of 2012 to early 2013, being compared with the average GI from 2000 to 2011, used as the reference period. Currently, the grassland areas in Zona da Mata occupy approximately 1.2 million hectares. According to the used methods, 177,322 ha (14.61\%) of these grassland areas have very low vegetative growth; 577,698 ha $(45.96 \%)$ have low growth; 433,475 ha (35.72\%) have balanced growth; 39,980 ha (3.29\%) have high growth; and 5,032 ha $(0.41 \%)$ have very high vegetative growth. The grasslands had predominantly low vegetative growth during the studied period, and the NDVI/Modis series is a useful source of data for regional assessments.

Index terms: growth index, pastures, remote sensing, time series, Zona da Mata.

\section{Crescimento vegetativo de pastagens baseado em dados hipertemporais de NDVI do sensor Modis}

\begin{abstract}
Resumo - O objetivo deste trabalho foi analisar o desenvolvimento das pastagens na Zona da Mata, em Minas Gerais, entre 2000 e 2013, com uso de um parâmetro baseado no índice de crescimento do índice de vegetação da diferença normalizada (NDVI) a partir de séries de dados do "moderate resolution imaging spectrodiometer" (Modis). A partir dos perfis temporais do NDVI, usados como indicadores das condições edafoclimáticas, estimou-se o índice de crescimento (IC) para períodos de 16 dias da estação primaveril de 2012 até o início de 2013, o qual foi comparado ao IC médio de 2000 a 2011, período usado como referência. A área atual de pastagens na Zona da Mata é de aproximadamente 1,2 milhão de hectares. De acordo com os métodos usados, 177.322 ha $(14,61 \%)$ destas áreas de pastagens apresentam crescimento vegetativo muito baixo; 577.698 ha (45,96\%), crescimento baixo; 433.475 ha $(35,72 \%)$, crescimento equilibrado; 39.980 ha $(3,29 \%)$, crescimento alto; e 5.032 ha $(0,41 \%)$, crescimento vegetativo muito alto. As pastagens apresentaram baixo crescimento vegetativo durante o período estudado, e a série NDVI/Modis é fonte útil de dados para a avaliação regional.
\end{abstract}

Termos para indexação: índice de crescimento, pastagens, sensoriamento remoto, séries temporais, Zona da Mata.

\section{Introduction}

Dairy production in the state of Minas Gerais, Brazil, has a complex geography due to its distribution, and is affected by underlying environmental and socioeconomic factors. With milk production reaching approximately 9 billion liters in 2014 (Instituto..., 2015), which is approximately $27 \%$ of the national total, productive clusters occur within the established dairy regions. At the same time, there is a constant expansion in production according to the time series data from the agricultural census. The region of Zona da Mata represents $10 \%$ of the dairy production in the state. Although several physical-environmental and socioeconomic factors affect the distribution of the land suitability for and the efficiency of the production systems, many of the traditional areas that are part of the state's extensive dairy chain are aggregated in this region. 
The Zona da Mata Region is composed of important micro-regions, namely, Cataguases, Juiz de Fora, Leopoldina, Manhuaçu, Muriaé, Ponte Nova, Ubá, and Viçosa, in which extensive livestock, rugged topography, and complex production systems are factors that should be included in the biophysical assessments of grasslands. It should be noted that monitoring growth conditions in grasslands is challenging due to marked seasonality, including decreased photosynthetic activity in early spring, and to extensive and inadequately managed irregular grazing, which promotes vegetation degradation (Nascimento et al., 2006). The region of Zona da Mata in the state of Minas Gerais is characterized by a large mosaic of land uses, composed of annual and perennial crops. The grassland areas extend to approximately 1.2 million hectares, which are distributed throughout the region and are under different degrees of management.

Normalized difference vegetation index/moderate resolution imaging spectroradiometer (NDVI/Modis) remote sensing data can facilitate the analysis of herbaceous vegetation growth. In addition, the adoption of a spatial-temporal metric from remote sensing data for assessing grassland degradation may reveal long-term persistent conditions. Vegetation consumption by herds is an important dynamics in evaluating and defining protocols based on vegetation indices when annual and inter-annual averages present good correlations with grassland status (Wessels et al., 2007; Reeves \& Bagget, 2014). This phenomenon is present mainly in tropical grassland regions, where most of the rainfall occurs during the growing season and corresponds to changes in the vegetation index; however, the onset of spring in dry grasslands or moist environments indicates a strong relationship with climate data (Xin et al., 2015). Remote sensing data can greatly assist in the identification and mapping of existing grasslands and their conditions. The NDVI data available in the Modis sensor database can be used to generate synoptic information in order to indicate the photosynthetic activity of pastures. Although the vegetation indices and the absorbed photosynthetically active radiation are not linearly related to the leaf area index (LAI), with LAI saturation values of approximately 3 , this index forms a nearly linear relationship with the photosynthetic activity of the canopy (Sellers et al., 1992).
Grasslands have been studied and monitored using satellite data in several ecosystems, which has indicated that the net primary productivity of pasture biomass measured in the field is correlated with Modis data and that better results are obtained during the growing season. In a study carried out in China, the linear trend of the average NDVI/advanced very high resolution radiometer (AVHRR), of the National Oceanic and Atmospheric Administration (NOAA), during the peak season, was analyzed, indicating that anthropogenic actions and biophysical factors were dominant regarding grassland degradation (Zhang et al., 2007). However, the heterogeneous nature of environmental, physical, and social factors hinders the association or correlation with vegetation productivity. Huang et al. (2009) discriminated between invasive species in grasslands by using NDVI/Modis data in semiarid regions, whereas $\mathrm{Li}$ et al. (2013) analyzed the inter-annual variations of pasture vegetation growth trends through NDVI/Modis data and the MOD13Q1 product, observing a direct relationship with cumulative rainfall. According to Jensen (2009), the analysis of seasonal NDVI data time series has provided a method for estimating the net primary productivity of several types of biomes and for monitoring phenological patterns. Fontana et al. (2008) showed that the Modis sensor is more efficient than the AVHRR sensor for phenological studies of alpine grasslands, with a high correlation between NDVI and field data. In another study, Jonas et al. (2008) analyzed Swiss meteorological data correlated with phenological trends of grasslands in the Alps, by considering biomass levels. Cristiano et al. (2015) pointed out that the biomass of $\mathrm{C} 3$ and $\mathrm{C} 4$ grasses is concentrated in subsoil and roots when remote sensing analysis are limited to grassland phytophysiognomy. Even though some invasive and leguminous plants or tree and shrub species, especially in their early stages, can be palatable and digestible to animals, they can obscure geospatial results. Thaikua et al. (2015) found that anatomy, morphology, and hydrology effects on Urochloa (Syn. Brachiaria) phenology may be useful when determining selection criteria for digestibility in experimental areas in Japan. As highlighted by Akiyama \& Kawamura (2007), remote sensing and geographic information systems (GIS) are promising approaches for monitoring grasslands that have 
recently become useable due to the creation of new sensor systems suitable for evaluating degradation.

Biudes et al. (2014) obtained good correlations between Modis products and rainfall in studies on the Brazilian forest. This shows that, in addition to various physical and environmental factors, NDVI is a general indicator of climate conditions. In a study of soybean crops in southern Brazil, Leivas et al. (2014) showed that NDVI series can efficiently indicate drought and rainy conditions from rainfall data and the standard vegetation index. Therefore, the scale of study suggests attention to microclimate measures and medium or microscale mapping. Fonseca et al. (2007), based on soil effects, attempted to use Landsat 7 images and an agrometeorological model to predict the availability of forage in municipalities in southern Brazil, but obtained unsatisfactory results. Nascimento et al. (2006) and Chagas et al. (2009) identified grassland degradation levels through high resolution images, whose detailed soil exposition hindered the classification of the areas with higher degradation levels.

Moreover, the accumulation or sum of the vegetation index values can determine the types or levels of grassland degradation (Anjos et al., 2013), with variance due to identification capacity, depending on the spatial resolution of the images. Another method for identifying the level of degradation is to monitor the vegetative growth in grasslands for a certain period of time and to compare the obtained data to a long-term vegetation index data series. Several authors have directed their research efforts towards the development of computational methodologies using GIS and remote sensing data time series to characterize pastures and other ground targets (Verbesselt et al., 2010; Li \& Guo, 2012; Victoria et al., 2012; Xu et al., 2013). Applications focused on small or medium-sized areas require high-resolution images that are compatible with limited case studies. However, for large areas, the Modis sensor becomes suitable for monitoring contiguous land uses. Modis images are distributed free of charge by the United States Geological Survey.

In the present study, the filtering method through outlier detection (compatible to cubic spline wavelet in the second level of decomposition) was used in NDVI/ Modis (MOD13Q1 product) time series, corrected geometrically and atmospherically, which allows control over the temporal pattern of the curves and encourages grassland monitoring in extensive regions.
The objective of this work was to analyze the development of grasslands in Zona da Mata, in the state of Minas Gerais, Brazil, between 2000 and 2013, using a parameter based on the growth index of the NDVI from the Modis data series.

\section{Materials and Methods}

Zona da Mata (Figure 1) is a region characterized by a strong predominance of rugged relief, with soils formed by granite and gneiss, and an economy based on agriculture and industries (Nascimento et al., 2006; Sá Junior, 2009). The region, with an average altitude of $650 \mathrm{~m}$, has a subtropical climate, Cwa, according to Köppen, with dry winter, with temperatures below $18^{\circ} \mathrm{C}$, and rainy summer, with temperatures above $22^{\circ} \mathrm{C}$, and average rainfall of $1,200 \mathrm{~mm}$.

Zona da Mata is formed by several micro-regions. The micro-region of Manhuaçu has a subtropical climate in elevation (Cwb), an economy based on coffee crops and dairy and beef cattle, showing milk production of 44.3 million liters in 2014, and a high negative variation in the amount of farms, of about $-27.43 \%$ in the last two decades. The micro-region of Ponte Nova has a predominant subtropical climate ( $\mathrm{Cwa}$ and $\mathrm{Cwb}$ ), with an economy based on agriculture, rendering services, and industries, with milk production of 102 million liters, but a lower negative variation in the amount of farms, of about $-7.80 \%$. The micro-regions of Muriaé, Cataguases, and Ubá are characterized by the predominance of the tropical climate (Aw), with an economy oriented towards agriculture (dairy livestock) and agro-industries (dairy and furniture), whose milk production was about 120 million liters in 2014, with variation in the amount of farms of about $-20 \%$ in 20 years, for each micro-region. The micro-regions of Juiz de Fora and Viçosa have a prevailing subtropical climate (Cwa), and economic activities related to dairy farming, rendering services, industries, and textile and agro-industries (dairy), showing similar variation in the amount of farms, of about $-10 \%$, but differing in milk production, of 217.4 and 55.7 million liters in 2014, respectively. It should be noted that the micro-region of Manhuaçu is the only one that showed variation in milk production of $80 \%$ in the last four decades; all the other micro-regions presented a positive variation of 200-270\%. In the last decade, however, the variation in milk production was much lower, with the exception 
of the micro-region of Juiz de Fora, which presented important positive variation (Instituto..., 2015).

The time series of grasslands in Zona da Mata have been characterized based on the identification of some pure pixels, which represent vegetation indices that are typical of grasslands from 2000 to 2013, through reference iconography (medium and high-resolution images, as well as Google Earth data), field knowledge, sample points, and descriptive data. NDVI is the most widely used vegetation index because it is directly correlated with the degree of photosynthetic production and simultaneous application to different vegetation physiognomies, which facilitates analysis. NDVI is primarily used to identify different types of land use and cover, notably vegetation types with lower tree and shrub densities, and is calculated from the ratio of the difference between near infrared $\left(\rho_{\text {nir }}\right)$ and red $\left(\rho_{\text {red }}\right)$ reflectance measurements and their sum, which results in a value that summarizes the degree of photosynthetic activity of the vegetation in a given area $\left(\mathrm{NDVI}=\left(\rho_{\text {nir }}-\rho_{\text {red }}\right) /\left(\rho_{\text {nir }}+\rho_{\text {red }}\right)\right.$.

This index is especially applicable in studies of large areas of land with diverse biomes and agricultural activities in complex mosaics because it can detect seasonal cycles and phenological phenomena that may or may not be associated with the management regime. The Modis sensor aboard the Terra satellite is an initiative of NASA's Earth Observing System (EOS) program and captures images across different ranges of the electromagnetic spectrum to produce useful information regarding the atmosphere and environment. To obtain the areas of grasslands (natural, cultivated, and perennial) and non-grasslands, the NDVI/Modis database was used (Hott et al., 2011). Characteristic NDVI intervals for the grasslands of the micro-regions of the region of interest were investigated, and a classification scheme was used to distinguish between grasslands and other areas. NDVI data points to the senescence of vegetation in pastures in early May, during which a decline in rainfall occurs, emphasizing this category of vegetation. For the present study, the MOD13Q1 mosaic for available dates in 2009, 2010, and 2011 was generated, as well as the H13V10, H13H11, H14V10, and H14V11 tiles, and the month of May 2010 (composition from May $9,2010)$ was selected, for which the ranges of NDVI

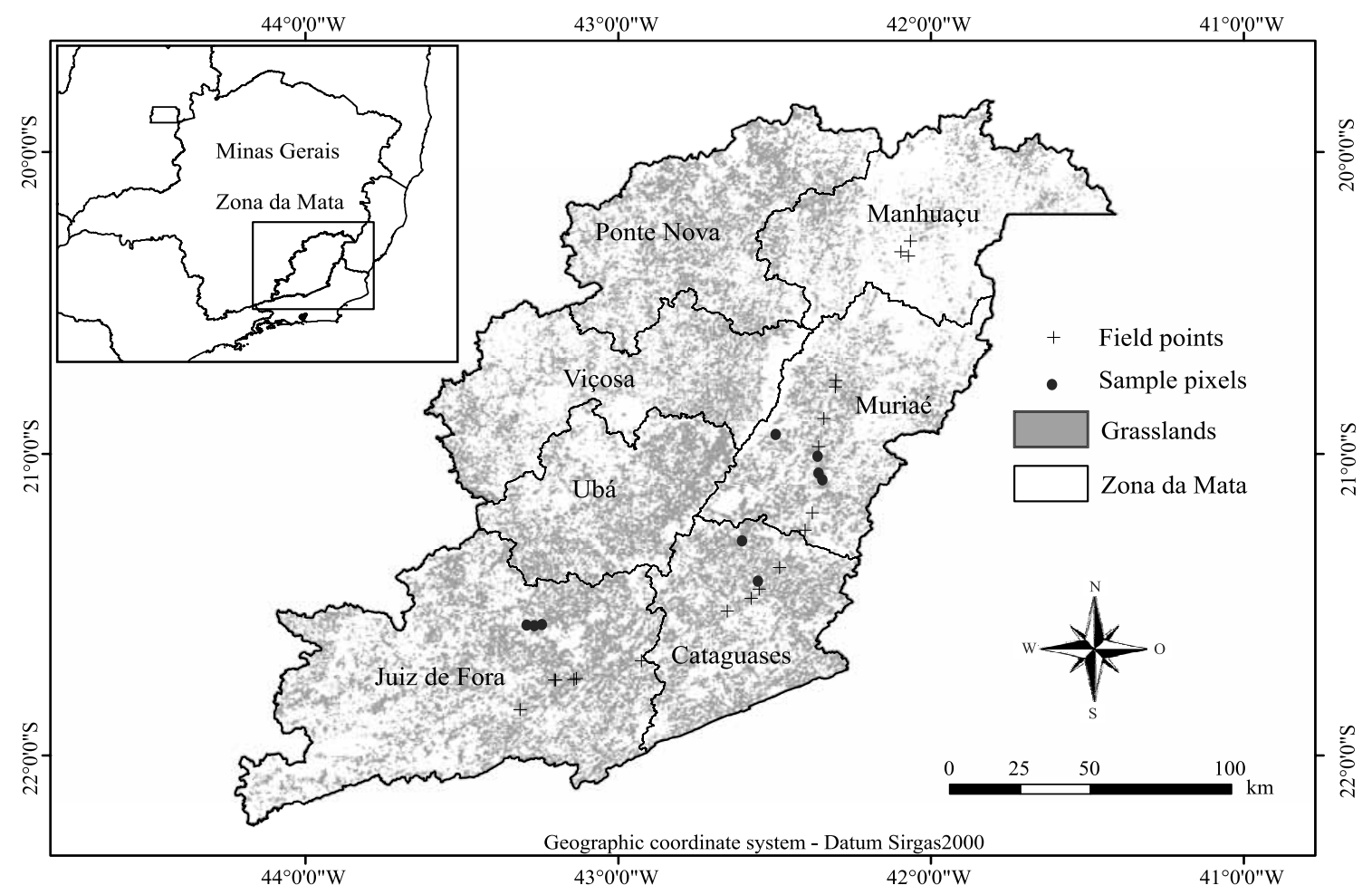

Figure 1. Location of the study area, micro-regions, and reference points of the Zona da Mata Region, in the state of Minas Gerais, Brazil. 
were tabulated, resulting in an average interval of 0.55 to 0.65 , with a standard deviation of 0.02 . Grassland areas were classified by merging the NDVI intervals together with the assessment maps produced by supervised classification and imagery interpretation, based on random sampling, with the distribution of 700 samples, which was twice the number of samples recommended by the chi-square distribution, with $35 \%$ occupancy classes of interest at the $95 \%$ confidence level. The NDVI product from the MOD13Q1 data was used for regarding the evolution of grassland growth in a hyper-temporal series beginning on February 18, 2000, and ending on January 1, 2013, at a spatial resolution of $250 \mathrm{~m}$ and a temporal resolution of 16 days. The 16-day-interval NDVI/Modis products are evaluated regarding their quality and corrected in relation to geometric and atmospheric conditions. The pattern of rainfalls was analyzed, based on data obtained by Instituto Nacional de Pesquisas Espaciais (INPE), the Brazilian Institute for Space Research, from meteorological stations in the municipalities of Manhuaçu, Viçosa, and Juiz de Fora during several years. Overall, good rainfall distribution was recorded, and an equivalent response of the vegetation index was observed, corresponding with the NDVI behavior registered by Leivas et al. (2014).

Numerous smoothing methods for time series are suitable for different objectives, such as the Savitzky-Golay filter (Jönsson \& Eklundh, 2004), wavelet transforms (Sakamoto et al., 2005), and other mathematical filtering and smoothing methods, which can significantly change the temporal patterns that are expressed in graphs. To gain control over smoothing applied to the temporal profiles, in the present study, filtering was conducted by using the root mean square method after the removal of outliers from the detection results and by applying data substitution as follows. A test was conducted to detect outliers in a temporal observation window with ten observations, according to the relationship below: $-1,1 \mathrm{~S}_{\mathrm{i}}+\overline{\mathrm{r}}>\mathrm{NDVI}_{\mathrm{o}}>+1,1 \mathrm{~S}_{\mathrm{i}}+\overline{\mathrm{r}}$ in which $\mathrm{NDVI}_{0}$ is the outlier for the time interval; $\mathrm{S}_{\mathrm{i}}$ is the standard deviation for the series of ten observations; and $\bar{r}$ is the average of the series of ten observations. After the identification of outliers, the substitution rule for adopting the root mean square was defined with a window of four observations in the series, and the entire temporal analysis was implemented in GIS. The grassland growth index (GI) was obtained from the ratio between the NDVI values observed in the spring season of 2012 and the average NDVI score from 2000 to 2011, as described by Xu et al. (2013) for the region of interest, using the following equation: $\mathrm{GI}=\left(\mathrm{NDVI}_{\mathrm{m}}-\mathrm{NDVI}_{\mathrm{n}}\right) /\left(\mathrm{NDVI}_{\mathrm{m}}+\mathrm{NDVI}_{\mathrm{n}}\right)$ in which GI is the vegetative growth rate of the grasslands; $\mathrm{NDVI}_{\mathrm{m}}$ represents the vegetation index value at date $\mathrm{m}$; and $\mathrm{NDVI}_{\mathrm{n}}$ is the average of the vegetation indices for the equivalent period in previous years. Therefore, $\mathrm{NDVI}_{\mathrm{m}}$ is the vegetation index value for every 16 days between September 2012 and early January 2013, and $\mathrm{NDVI}_{\mathrm{n}}$ designates the average NDVI from September to January 2000 to 2011. The early-september and early-January growth season periods correspond to start-of-season (SOS) and to peak-of-season (POS) metrics; both are important in grassland phenology and describe the behavior and restoration capacity of the vegetation. The growth index was classified based on pasture performance observed in the field, temporal profiles, and high-resolution iconography, and the resulting indices were compared to the condition of the sampled pixels and of the known and visited regions (Figure 2) as part of a field campaign that covered $800 \mathrm{~km}$. Several ground points were observed between September 2014 and April 2015 when data were collected, and the corresponding map results and legends were evaluated. A total of 20 ground points were continuously monitored. For this, the ground points were visited, and annotations regarding the conditions of the grasslands in the four cardinal directions were made, for a total of 100 field observations, using the global positioning system (GPS). Several areas in Zona da Mata were visited using state and federal roads during the dry and rainy seasons. The grassland growth index classes were divided into: very low, <-0.05; low, $-0.05-0.0$; balanced, 0.0-0.05; high, 0.05-0.1; and very high, $>0.1$, according to the distribution of the calculated index values, reference materials, field observations, and observation of histogram and statistical agreement through intervals of confidence based on chi-square distribution. The overall goal was to assess the evolution of pastures for each 16-day period during the evaluated months relative to the historical average, aiming to establish a pattern of remote sensing-based monitoring on a mask or grassland map from 2010. To estimate the area occupied by each grassland growth index class for the entire spring period of 2012, the 
sum of the areas in each class was calculated for each date analyzed from September to January.

\section{Results and Discussion}

The grassland conditions observed in the landscape were compared with the results obtained by the growth index, with a confidence level of $95 \%$. Strong qualitative and quantitative correlations were found between the field campaign data and the map of grassland growth. The accuracies of the grassland map obtained by the producer and user were approximately 74.24 and $100 \%$, with low errors of omission and commission and no errors related to the masked areas without grasslands.
In the present study, a Kappa index of 0.91 and an overall accuracy of $91.57 \%$ were obtained (Table 1 ). Reeves \& Baggett (2014), for example, used statistical parameters from NDVI time series, such as correlation and autocorrelation. In the analysis of the present study, all of the sampled pure pixel profiles were homogeneous in terms of means and standard deviations, showing high degree of correlation, of approximately 0.8 , in the spatially and temporally similar pixel series. Through the removal of outliers and the application of the root mean square filter, consistently patterned series were obtained, for which the temporal pattern was approximated while maintaining a balance between low and high frequencies, necessary to evaluate
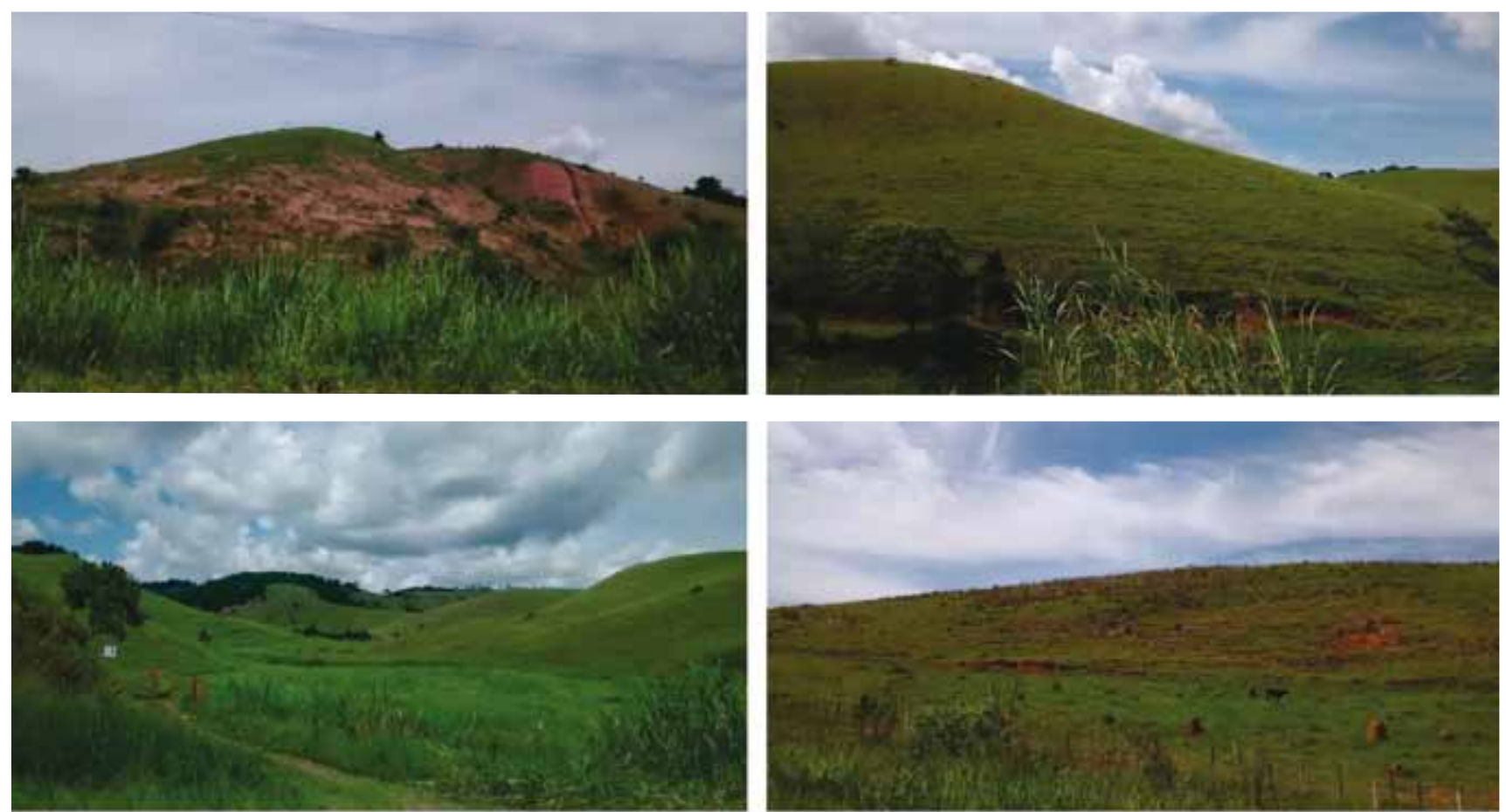

Figure 2. Photographs of field points representing grassland conditions in the south and southeast portions of the Zona da Mata Region, located in the state of Minas Gerais, Brazil.

Table 1. Accuracy of the grassland map of the Zona da Mata Region, in the state of Minas Gerais, Brazil, from the reference samples.

\begin{tabular}{|c|c|c|c|c|c|c|c|}
\hline \multirow[t]{2}{*}{$\overline{\text { Classes }}$} & \multicolumn{2}{|c|}{ Reference data } & \multirow[t]{2}{*}{ Total } & \multicolumn{2}{|c|}{ Accuracy } & \multicolumn{2}{|c|}{ Error } \\
\hline & Grasslands & Others & & User & Producer & Commission & Omission \\
\hline Grasslands & 170 & 0 & 170 & 100.00 & 74.24 & 0.00 & 25.76 \\
\hline Others & 59 & 471 & 530 & 88.87 & 100.00 & 11.13 & 0.00 \\
\hline Total & 229 & 471 & 700 & - & - & - & - \\
\hline Kappa index & 0.91 & & & & & & \\
\hline Overall accuracy & 91.57 & & & & & & \\
\hline
\end{tabular}


vegetation growth, mitigate atmospheric effects, and detect degradation processes. The hyper-temporal approach can adequately characterize the dynamics of land use, which, despite the existence of traditional areas with pasture crops, also has semi-deciduous arboreal vegetation and climate conditions that support rapid regeneration, which can cause a high degree of spectral-temporal confusion (Jesus \& Epiphanio, 2010; Wondrade et al., 2014). Therefore, a first step in the characterization of grassland areas through satellite imaging is the analysis of historical series, whose pixels at the same geographical locations are monitored over time and can indicate permanent or temporary changes in land use.

In the present study, a moderate resolution, derived from NDVI/Modis, at the regional scale, was used because a high temporal resolution was available. However, recently, efforts have been made to merge data properties to obtain images with high spatial and temporal resolutions by using algorithms, such as the spatial and temporal adaptive reflectance fusion model (STARFM) (Zhang et al., 2016), which could support photosynthetic activity evaluations with higher temporal and spatial resolutions that partially maintain the original coarse data. Therefore, based on a method for estimating the growth index at a moderate scale using the Modis database, Xu et al. (2013) observed a predominance of areas with stable or balanced growth in temperate grassland development. In the present study, the evaluated growing conditions were those of grasslands in tropical regions, where rainfall is well distributed in spring. Based on the methodology used in Zona da Mata, 177,322 ha (14.61\%) of grasslands were classified as areas with very low vegetative growth during the study period; 577,698 ha $(45.96 \%)$, as having low growth; 433,475 ha $(35.72 \%)$, as having balanced growth; 39,980 ha (3.29\%), as having high growth; and 5,032 ha $(0.41 \%)$, as having very high vegetative growth (Table 2). The area occupied by grasslands with balanced growth increased at the end of spring, whereas the areas with low or very low growth decreased (Table 3). However, the area of grasslands with low growth remained high throughout the study period, indicating low photosynthetic activity when compared with historical series, which is a clear sign of degradation from overgrazing, erosion, and poor soil fertility, as well as of soil worsening and climate conditions (Nascimento et al., 2006; Chagas et al.,
2009). The predominant vegetation development class was low or very low, for which the intensity pattern of the photosynthetically active vegetation denotes unstable growth conditions, which accounted for $72 \%$ of the area in late September. According to Wessels et al. (2007), the degradation in grasslands presents strong long-term effect on the response of NDVI time series. The most evident aspects of grassland degradation were highlighted, and the evolution of the growth index for every week of the spring season of 2012 was compared with the historical series (Figure 3). The portions with lower vegetative growth index values are the northwest, central, and southeast ones of Zona da Mata. The high and very high growth index classes remained below $10 \%$ of the area for the period, starting at $6.1 \%$ in early September

Table 2. Total grassland area of the Zona da Mata Region, in the state of Minas Gerais, Brazil, for each growth index class in the spring of 2012 and respective percentage.

\begin{tabular}{lcc}
\hline Grassland growth & \multicolumn{2}{c}{ Total grassland } \\
\cline { 2 - 3 } index $^{(1)}$ & Area (ha) & Area (\%) \\
\hline Very low & 177,322 & 14.61 \\
Low & 557,698 & 45.96 \\
Balanced & 433,475 & 35.72 \\
High & 39,980 & 3.29 \\
Very high & 5,032 & 0.42 \\
\hline Total & $1,213,507$ & 100 \\
\hline
\end{tabular}

${ }^{(1)}$ Quantitative and qualitative statistical analysis by the chi-square table $\left(\chi^{2} 0.95\right)$ with calculated $p$-value of $0.92(p>0.05)$, indicating independence among growth index classes, which were defined through field campaign and geographic information systems (GIS).

Table 3. Percentage of the grassland area of the Zona da Mata Region, in the state of Minas Gerais, Brazil, for the growth index classes for each 16-day period from September 2012 to January 2013.

\begin{tabular}{lcccccc}
\hline Date & \multicolumn{5}{c}{ Grassland area (\%) } & Total \\
\cline { 2 - 6 } & Very low & Low & Balanced & High & Very high & \\
\hline Sep. 13, 2012 & 16.15 & 42.22 & 35.53 & 4.95 & 1.15 & 100.0 \\
Sep. 29, 2012 & 26.91 & 45.30 & 24.08 & 2.98 & 0.73 & 100.0 \\
Oct. 15, 2012 & 22.03 & 46.34 & 28.14 & 3.00 & 0.49 & 100.0 \\
Oct. 31, 2012 & 17.09 & 47.91 & 31.54 & 3.12 & 0.34 & 100.0 \\
Nov. 16, 2012 & 11.65 & 46.05 & 38.54 & 3.52 & 0.24 & 100.0 \\
Dec. 2, 2012 & 8.58 & 44.92 & 42.63 & 3.69 & 0.18 & 100.0 \\
Dec. 18, 2012 & 7.01 & 44.21 & 45.42 & 3.23 & 0.13 & 100.0 \\
Jan. 1, 2013 & 7.47 & 50.71 & 39.89 & 1.86 & 0.07 & 100.0 \\
\hline
\end{tabular}


and ending at approximately $2 \%$ at the beginning of January 2013; the balanced growth class was $24 \%$ in late September and reached $45 \%$ in early December (Figure 4). By observing the tabulation produced by GIS (Table 4), the micro-regions of Cataguases, Muriaé, and Juiz de Fora, respectively, accounted for approximately 48,47 , and $46 \%$ of the grasslands, with low growth in the southeastern and southern portions of Zona da Mata. During the same period, nearly half of the Juiz de Fora and Viçosa areas were classified as having balanced growth in the south and west. Between September and early January, all of the micro-regions had low growth grasslands, especially Juiz de Fora and Cataguases, with an average of 52\% of their areas classified as having low growth, which denotes good potential of increase in milk production if adequate farming practices are adopted, considering the importance of these micro-regions for the dairy chain; an increase in production was also observed in the last decade (Instituto..., 2015). The percentages of the micro-regions that contained grasslands classified as of high or very high growth, however, were small, of 6 and 8\%, respectively, for Viçosa and Manhuaçu. Areas with low or very low grassland growth, such as Ponte Nova, were also observed, in which $74 \%$ of the grazing area was classified as having low or very low growth. This finding could indicate the instability of the development of grasslands in this micro-region and accounted for approximately $21 \%$ of the balanced growth class, denoting a reasonable vegetation cover level and indicating that the average NDVI did not increase.
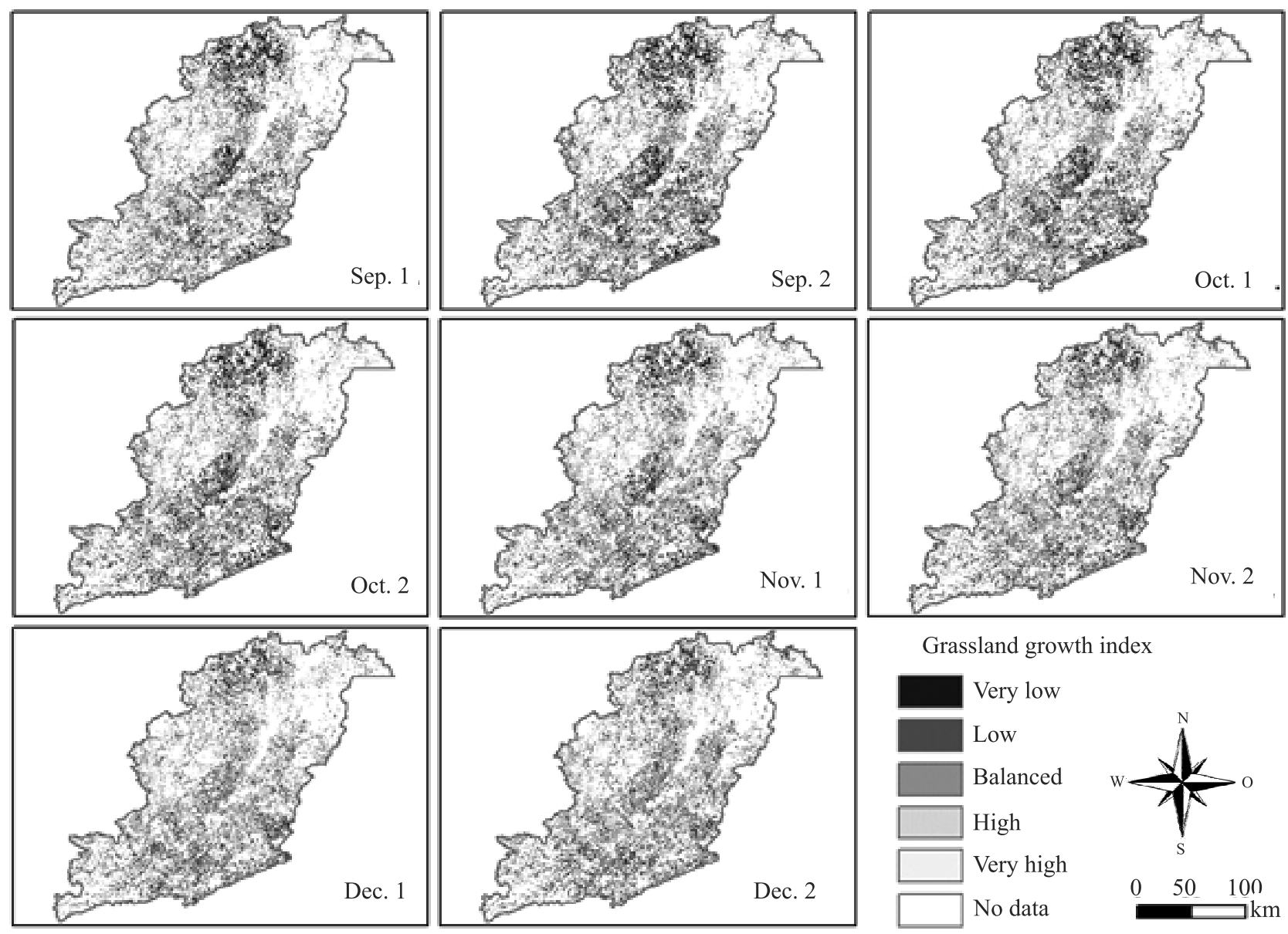

Grassland growth index

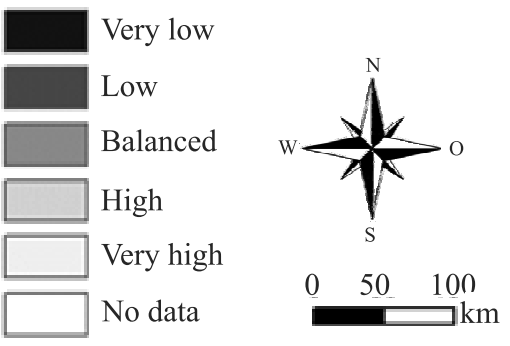

Figure 3. Distribution and evolution of the grassland growth index of the Zona da Mata Region, in the state of Minas Gerais, Brazil, for half-month periods of historical series. 
The 16-day NDVI data allow for the analysis of phenology and inter- and intra-annual changes in land use because they are available and have a frequency suitable for temporal studies; pixels that continue to exhibit the behavior of a certain crop or land use over time are considered temporally pure. The NDVI/Modis time series is a potentially useful data source for the regional evaluation of grasslands (Xu et al., 2013).

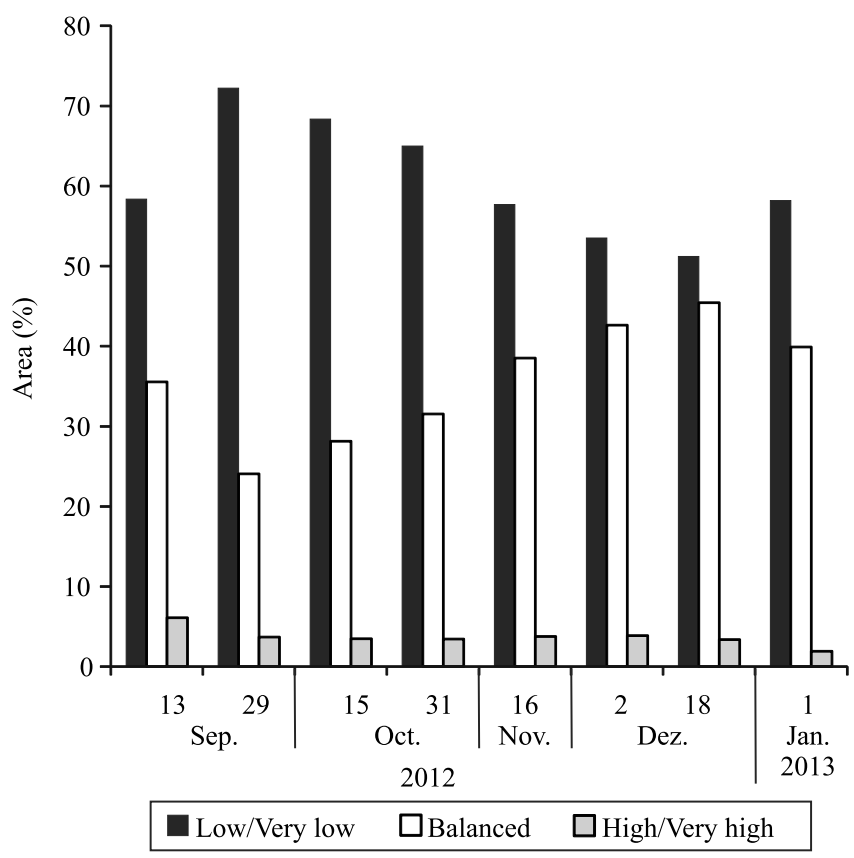

Figure 4. Percentage of the total pasture area of the Zona da Mata Region, in the state of Minas Gerais, Brazil, by grouping growth index classes.

Table 4. Percentage of the total grassland area for the growth index classes of each micro-region of the Zona da Mata Region, in the state of Minas Gerais, Brazil, in the spring of 2012.

\begin{tabular}{lrccccc}
\hline Micro-region & \multicolumn{5}{c}{ Total grassland area (\%) } & \multirow{2}{*}{$\begin{array}{c}\text { Total } \\
\text { (\%) }\end{array}$} \\
\cline { 2 - 6 } & Very low & Low & Balanced & High & Very high & \multicolumn{1}{c}{ (\%) } \\
\hline Cataguases & 19.13 & 52.59 & 25.47 & 2.36 & 0.45 & 14.25 \\
Juiz de Fora & 8.57 & 52.67 & 35.73 & 2.46 & 0.56 & 27.39 \\
Manhuaçu & 17.21 & 36.57 & 38.12 & 7.54 & 0.55 & 6.70 \\
Muriaé & 6.50 & 48.23 & 42.72 & 2.36 & 0.19 & 11.46 \\
Ponte Nova & 35.48 & 39.91 & 21.94 & 2.39 & 0.28 & 15.08 \\
Ubá & 13.56 & 45.36 & 37.24 & 3.43 & 0.41 & 12.95 \\
Viçosa & 4.41 & 34.25 & 55.20 & 5.78 & 0.36 & 12.17 \\
\hline Total (\%) & 14.61 & 45.96 & 35.72 & 3.29 & 0.42 & 100.00 \\
\hline
\end{tabular}

According to the remote sensing results, appropriate management measures should be taken to advance the recovery of grasslands in order to achieve a high growth index in the portions of Zona da Mata with poor growth.

\section{Conclusions}

1. Large areas with low growth were detected in the region of Zona da Mata, in the state of Minas Gerais, Brazil, which is an indicative of the degradation process or of development stagnation during 2012.

2 . Low growth grasslands were observed in the micro-region of Juiz de Fora, indicating a loss of vegetative growth in the spring of 2012 .

3. Approximately $60 \%$ of the grasslands (755,000 ha) in Zona da Mata were classified as having low or very low vegetative growth throughout the period, indicating a spring season with weak recovery compared with the historical series.

4. Zona da Mata shows an overall degradation of the grasslands, which can be continuously monitored through the growth index method, using the novel filtering method for time series.

\section{References}

AKIYAMA, T.; KAWAMURA, K. Grassland degradation in China: methods of monitoring, management and restoration. Grassland Science, v.53, p.1-17, 2007.

ANJOS, V.S.; SANO, E.E.; BEZERRA, H. da S.; ROSA, R. Caracterização espectro-temporal de pastagens do Triângulo Mineiro utilizando dados MODIS EVI2 (2000-2010). Sociedade e Natureza, v.25, p.205-215, 2013. DOI: 10.1590/ S1982-45132013000100016.

BIUDES, M.S.; MACHADO, N.G.; DANELICHEN, V.H. de M.; SOUZA, M.C.; VOURLITIS, G.L.; NOGUEIRA, J. de S. Ground and remote sensing-based measurements of leaf area index in a transitional forest and seasonal flooded forest in Brazil. International Journal of Biometeorology, v.58, p.1181-1193, 2014. DOI: $10.1007 / \mathrm{s} 00484-013-0713-4$.

CHAGAS, C.S.; VIEIRA, C.A.O.; FERNANDES FILHO, E.I.; C. JÚNIOR, W. de. Utilização de redes neurais artificiais na classificação de níveis de degradação em pastagens. Revista Brasileira de Engenharia Agrícola e Ambiental, v.13, p.319-327, 2009. DOI: $10.1590 /$ S1415-43662009000300014.

CRISTIANO, P.M.; POSSE, G.; DI BELlA, C.M. Total and aboveground radiation use efficiency in $\mathrm{C} 3$ and $\mathrm{C} 4$ grass species influenced by nitrogen and water availability. Grassland Science, v.61, p.131-141, 2015. DOI: 10.1111/grs.12086.

FONSECA, E.L. da; FORMAGGIO, A.R.; PONZONI, F.J. Estimativa da disponibilidade de forragem do bioma Campos 
Sulinos a partir de dados radiométricos orbitais: parametrização do submodelo espectral. Ciência Rural, v.37, p.1668-1674, 2007. DOI: $10.1590 / \mathrm{S} 0103-84782007000600025$.

FONTANA, F.; RIXEN, C.; JONAS, T.; ABEREGG, G.; WUNDERLE, S. Alpine grassland phenology as seen in AVHRR, VEGETATION, and MODIS NDVI time series - a comparison with in situ measurements. Sensors, v.8, p.2833-2853, 2008.

HOTT, M.C.; FONSECA, L.D’A.M.; SOUZA, R.C.S.N.P. Cenário ambiental para a produção de leite considerando a legislação sobre Áreas de Preservação Permanente na Zona da Mata e Campo das Vertentes em Minas Gerais. In: SIMPÓSIO BRASILEIRO DE SENSORIAMENTO REMOTO, 15., 2011, Curitiba. Anais. São José dos Campos: INPE, 2011. p.4504-4511. Editado por José Carlos Neves Epiphanio e Lênio Soares Galvão.

HUANG, C.; GEIGER, E.L.; VAN LEEUWEN, W.J.D.; MARSH, S.E. Discrimination of invaded and native species sites in a semi-desert grassland using MODIS multi-temporal data. International Journal of Remote Sensing, v.30, p.897-917, 2009. DOI: 10.1080/01431160802395243.

INSTITUTO BRASILEIRO DE GEOGRAFIA E ESTATÍSTICA. Banco de dados agregados. Sistema IBGE de Recuperação Automática - Sidra: Censo Agropecuário. [2015]. Available at: $\quad<$ http://www.sidra.ibge.gov.br/bda/acervo/acervo2. asp $\mathrm{e}=\mathrm{v} \& \mathrm{p}=\mathrm{CA} \& \mathrm{z}=\mathrm{t} \& \mathrm{o}=11>$. Accessed on: 2 Jun. 2015.

JENSEN, J.R. Sensoriamento remoto do ambiente: uma perspectiva em recursos terrestres. São José dos Campos: Parêntese, 2009. 598p.

JESUS, S.C. de; EPIPHANIO, J.C.N. Sensoriamento remoto multissensores para a avaliação temporal da expansão agrícola municipal. Bragantia, v.69, p.945-956, 2010. DOI: 10.1590/ S0006-87052010000400021.

JONAS, T.; RIXEN, C.; STURM, M.; STOECKLI, V. How alpine plant growth is linked to snow cover and climate variability. Journal of Geophysical Research, v.113, G03013, 2008. DOI: 10.1029/2007jg000680.

JÖNSSON, P.; EKLUNDH, L. TIMESAT - a program for analyzing time-series of satellite sensor data. Computers and Geosciences, v.30, p.833-845, 2004. DOI: 10.1016/j.cageo.2004.05.006.

LEIVAS, J.F.; ANDRADE, R.G.; VICTORIA, D. de C.; TORRESAN, F.E.; VICENTE, L.E.; TEIXEIRA, A.H. de C.; BOLFE, E.L.; BARROS, T.R. de. Avaliação do índice de vegetação padronizado no monitoramento indicativo de estiagens em períodos críticos da soja no Sul do Brasil. Revista Brasileira de Cartografia, n.66/5, p.1145-1155, 2014.

LI, Z.; GUO, X. A suitable NDVI product for monitoring spatiotemporal variations of LAI in semiarid mixed grassland. Canadian Journal of Remote Sensing, v.38, p.683-694, 2012. DOI: $10.5589 / \mathrm{m} 12-055$.

LI, Z.; HUFFMAN, T.; MCCONKEY, B.; TOWNLEY-SMITH, L. Monitoring and modeling spatial and temporal patterns of grassland dynamics using time-series MODIS NDVI with climate and stocking data. Remote Sensing of Environment, v.138, p.232-244, 2013. DOI: 10.1016/j.rse.2013.07.020.
NASCIMENTO, M.C.; RIVA, R.D.D.; CHAGAS, C. da S.; OLIVEIRA, H. de; DIAS, L.E.; FERNANDES FILHO, E.I.; SOARES, V.P. Uso de imagens do sensor ASTER na identificação de níveis de degradação em pastagens. Revista Brasileira de Engenharia Agrícola e Ambiental, v.10, p.196-202, 2006. DOI: 10.1590/S1415-43662006000100029.

REEVES, M.C.; BAGGETT, L.S. A remote sensing protocol for identifying rangelands with degraded productive capacity. Ecological Indicators, v.43, p.172-182, 2014. DOI: 10.1016/j. ecolind.2014.02.009.

SÁ JUNIOR, A. de. Aplicação da classificação de Köppen para o zoneamento climático do Estado de Minas Gerais. 2009. 101p. Dissertação (Mestrado) - Universidade Federal de Lavras, Lavras.

SAKAMOTO, T.; YOKOZAWA, M.; TORITANI, H.; SHIBAYAMA, M.; ISHITSUKA, N.; OHNO, H. A crop phenology detection method using time-series MODIS data. Remote Sensing of Environment, v.96, p.366-374, 2005. DOI: 10.1016/j.rse.2005.03.008.

SELLERS, P.J.; BERRY, J.A.; COLLATZ, G.J.; FIELD, C.B.; HALL, F.G. Canopy reflectance, photosynthesis, and transpiration. III. A reanalysis using improved leaf models and a new canopy integration scheme. Remote Sensing of Environment, v.42, p.187-216, 1992. DOI: 10.1016/0034-4257(92)90102-P.

THAIKUA, S.; EBINA, M.; KOUKI, K.; INAFUKU, M.; AKAMINE, H.; SHIMODA, K.; SUENAGA, K.; KAWAMOTO, Y. Preliminary evaluation on digestibility and the relation to morphology and water content of Brachiaria spp. and their heritability. Grassland Science, v.61, p.92-100, 2015. DOI: 10.1111/grs. 12082 .

VERBESSELT, J.; HYNDMAN, R.; NEWNHAM, G.; CULVENOR, D. Detecting trend and seasonal changes in satellite image time series. Remote Sensing of Environment, v.114, p.106-115, 2010. DOI: 10.1016/j.rse.2009.08.014.

VICTORIA, D. de C.; PAZ, A.R. da; COUTINHO, A.C.; KASTENS, J.; BROWN, J.C. Cropland area estimates using Modis NDVI time series in the state of Mato Grosso, Brazil. Pesquisa Agropecuária Brasileira, v.47, p.1270-1278, 2012. DOI: 10.1590/S0100-204X2012000900012.

WESSELS, K.J.; PRINCE, S.D.; CARROLL, M.; MALHERBE, $\mathrm{J}$. Relevance of rangeland degradation in semiarid northeastern South Africa to the nonequilibrium theory. Ecological Applications, v.17, p.815-827, 2007. DOI: 10.1890/06-1109.

WONDRADE, N.; DICK, O.B; TVEITE, H. GIS based mapping of land cover changes utilizing multi-temporal remotely sensed image data in Lake Hawassa Watershed, Ethiopia. Environmental Monitoring and Assessment, v.186, p.1765-1780, 2014. DOI: 10.1007/s10661-013-3491-x.

XIN, Q.; BROICH, M.; ZHU, P.; GONG, P. Modeling grassland spring onset across the Western United States using climate variables and MODIS-derived phenology metrics. Remote Sensing of Environment, v.161, p.63-77, 2015. DOI: 10.1016/j. rse.2015.02.003.

XU, B.; YANG, X.C.; TAO, W.G.; MIAO, J.M.; YANG, Z.; LIU, H.Q.; JIN, Y.X.; ZHU, X.H.; QIN, Z.H; LV, H.Y.; LI, J.Y. 
MODIS-based remote-sensing monitoring of the spatiotemporal patterns of China's grassland vegetation growth. International Journal of Remote Sensing, v.34, p.3867-3878, 2013. DOI: 10.1080/01431161.2012.762696.

ZHANG, J.; YAO, F.; ZHENG, L.; YANG, L. Evaluation of grassland dynamics in the Northern Tibet Plateau of China using remote sensing and climate data. Sensors, v.7, p.3312-3328, 2007. DOI: $10.3390 / \mathrm{s} 7123312$.

ZHANG, B.; ZHANG, L.; XIE, D.; YIN, X.; LIU, C.; LIU, G. Application of synthetic NDVI time series blended from Landsat and MODIS data for grassland biomass estimation. Remote Sensing, v.8, p.1-21, 2016.

Received on October 26, 2015 and accepted on May 16, 2016 